\title{
Tinjauan Penyebab Unclaimed Berkas Pasien BPJS Pada Rawat Jalan Di Rumah Sakit Umum Imelda Pekerja Indonesia
}

\author{
Ary Syahputra Wiguna \\ Program Studi D-III Perekam Medis dan Informasi Kesehatan, Universitas Imelda Medan
}

\begin{tabular}{l}
\hline \hline Article Info \\
\hline Article history: \\
Received Feb10, 2020 \\
Revised Feb 25, 2020 \\
Accepted Feb28, 2020 \\
\hline
\end{tabular}

Keywords:

BPJS

Unclaimed

Medical Record File

\begin{abstract}
ABSTRAK
A claim is a claim for recognition of the fact that someone has the right (has or has) of something. Medical records submitted to the BPJS whose medical conclusions are doubtful, due to incompatibility or incomplete data will be returned which is often called unclaim. The purpose of this study was to determine the cause of unclaimed BPJS files for patients on an outpatient basis based on the identification of inputs and processes. This type of research uses a qualitative method with phenomenology. When the study was conducted in March to May 2019 and the study was conducted at the General Hospital Imelda Indonesian Workers. Population and samples in the study were BPJS officers, amounting to 6 (six) people. Data was collected using interview guidelines. The results of the study showed that the cause of unclaimed BPJS files for patients on an outpatient basis based on input was human resources and lack of facilities, networks and software that often caused errors. Whereas based on the process is planning that still does not use SOP. It is recommended to the hospital to increase the number of human resources and facilities in processing claim files, repairing network and software errors, making SOPs for filing claims.
\end{abstract}

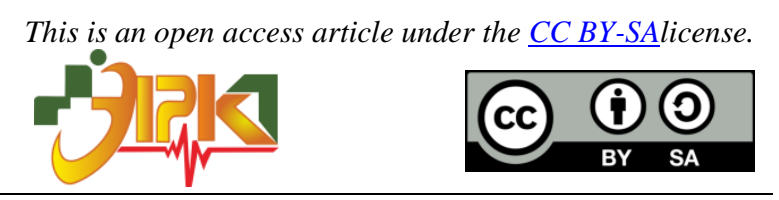

\section{Corresponding Author:}

Ary Syahputra Wiguna,

Program Studi D-III Perekam Medis dan Informasi Kesehatan,

Universitas Imelda Medan,

Jl. Bilal No. 52 Kelurahan Pulo Brayan Darat I Kecamatan Medan Timur, Medan - Sumatera Utara.

Email: aryesyah1@gmail.com

\section{PENDAHULUAN}

Undang-Undang Nomor 36 Tahun 2009 tentang Kesehatan menyatakan bahwa setiap orang berhak atas kesehatan dan setiap orang mempunyai hak yang sama dalam memperoleh akses atas sumber daya di bidang kesehatan serta setiap orang mempunyai hak dalam memperoleh pelayanan kesehatan yang aman, bermutu, dan terjangkau. Salah satu instansi pelayanan kesehatan masyarakat yaitu Rumah Sakit.

Rumah sakit ialah institusi pelayanan kesehatan yang menyelenggarakan pelayanan kesehatan perorangan secara paripurna yang menyediakan pelayanan rawat inap, pada rawat jalan, dan gawat darurat. Fungsi rumah sakit ialah menyelenggarakan pelayanan pengobatan dan pemulihan kesehatan, pemeliharaan dan peningkatan kesehatan perorangan, penyelenggaraan pendidikan dan pelatihan sumber daya manusia serta penyelenggaraan penelitian dan pengembangan serta penapisan teknologi bidang kesehatan. Salah satu kewajiban setiap rumah sakit ialah menyelenggarakan rekam medis (UU No. 44, 2009). 
Penyelenggaraan program BPJS mempunyai metode pembayaran. Metode pembayaran yang digunakan dalam program ini ialah metode pembayaran prospektif yaitu Casemix (Case Based Payment) dan sudah diterapkan mulai sejak tahun 2008 sebagai metode pembayaran pada Program Jaminan Masyarakat (Jamkesmas). Sistem casemix ialah pengelompokkan diagnosis dan prosedur dengan mengacu pada ciri klinis yang mirip/sama, penggunaan diagnosis biaya perawatan, pengelompokan dilakukan dengan menggunakan sebuah software grouper (Undang-undang no.24, 2011).

Klaim ialah tuntutan pengakuan atas suatu fakta bahwa seseorang berhak (memiliki atau mempunyai) atas sesuatu (KBBI). Klaim BPJS ialah pengajuan biaya perawatan pasien peserta BPJS oleh pihak rumah sakit kepada BPJS Kesehatan, dilakukan secara kolektif dan ditagihkan kepada pihak BPJS Kesehatan setiap bulannya.Fasilitas kesehatan rumah sakit, berkewajiban untuk melengkapi dokumen klaim BPJS sebelum diajukan kepada pihak BPJS Kesehatan untuk mendapatkan penggantian biaya perawatan sesuai dengan tarif Indonesia Case Base Groups. Kelengkapan dan keakuratan dokumen klaim BPJS yang ada pada rumah sakit meliputi rekapitulasi pelayanan dan berkas pendukung pasien yang terdiri dari Surat Eligibilitas Peserta (SEP), resume medis, keterangan diagnosa dari dokter yang merawat, dan bukti pelayanan, ketepatan koding, lainnya. Setelah itu BPJS Kesehatan akan melakukan persetujuan klaim dan melakukan pembayaran untuk berkas yang memang layak, namun untuk berkas yang tidak layak harus dikembalikan ke rumah sakit (Unclaimed) untuk dapat diperiksa kembali.

Penelitian sebelumnya yang berkaitan dengan analisis penyebab unclaimed berkas BPJS pasien rawat inap di rumah sakit umum Imelda Pekerja Indonesia (RSU IPI) Medan menyatakan sangat membantu pihak manajemen rumah sakit dalam menemukan ketidakcocokan atau ketidaklengkapan data-datanya (Valentina. \& Halawa, 2018). Penelitian sebelumnya yang berjudul analisis sistem pelepasan informasi rekam medis dalam menjamin aspek hukum kerahasiaan rekam medis di rumah sakit imelda pekerja indonesia medan menyatakan agar dapat meningkatkan kualitas pengetahuan mengenai keamanan informasi pasien dan integritas data dijaga dirumah sakit. Sehingga dapat terlaksananya penyelenggaraan akreditasi sesuai dengan prosedur yang ditetapkan oleh tim kars (komite akreditasi rumah sakit) (Panggabean \& Sianipar, 2018).

\section{METODE PENELITIAN}

A. Jenis Penelitian

Jenis penelitian ini dilakukan dengan menggunakan metode penelitian kualitatif dengan pendekatan fenomenologi. Pendekatan fenomenologi merupakan suatu metode penelitian yang kritis dan menggali fenomena yang ada secara sistematis (Saryono, 2013).Penelitian ini dilakukan dalam situasi yang alami, sehingga tidak ada batasan dalam memaknai atau memahami fenomena yang dikaji. Jenis penelitian ini digunakan untuk mengetahui penyebab pengembalian berkas (unclaimed) pasien BPJS Pada rawat jalan di RSU Imelda Pekerja Indonesia. Penelitian dilakukan pada bulan Oktober 2019 - Januari 2020. Penelitian ini dilakukandi RSU Imelda Pekerjaan Indonesia Medan berlokasi di JL. Bilal No.24 Pulo Brayan Darat I, Medan, Sumatra Utara.

B. Populasi

Populasi merupakan keseluruhan objek penelitian atau objek yang diteliti (Notoadmodjo, 2012).Populasi dalam penelitian ini ialah seluruh petugas yang ada di ruang BPJS di RSU IPI Medan yang berjumlah 6 orang.

C. Sampel dan Teknik Sampling

Sampel merupakan sebagian dari seluruh elemen yang menjadi objek penelitian (Isgiyanto, 2009). Adapun yang menjadi Informan atau nara sumber yang menjadi sampel dalam penelitian ini berjumalah 6 orang yaitu kepala ruangan BPJS RSU IPI 
1 orang, petugas koder BPJS RSU IPI terdiri dari 3 orang, petugas administrasi BPJS terdiri dari 2 orang.

D. Instrumen Penelitian

Instrumen penelitian ialah suatu alat pengumpul data yang digunakan untuk mengukur fenomena atau kejadian yang di amati, mencari informasi menggunakan data yang lengkap sehingga lebih mudah di olah (Sugiyono, 2014). Instrument yang digunakan dalam penelitian ini yaitu Dokumen rekam medis atau pengambilan data langsung pada objek sebagian sumber informasi dilapangan dengan menggunakan daftar checklist

E. Cara Pengumpulan Data

Instrumen ialah alat-alat yang akan digunakan untuk pengumpulan data (Arikunto, 2010). Instrumen yang digunakan pedoman wawancara dan direkam menggunakan alat rekorder.

F. Analisis Data

Dalam penelitian ini analisa data dilakukan secara deskriptif kualitatif yaitu hanya menggunakan penalaran tanpa menggunakan rumus statistik atau data perhitungan, sehingga diperoleh gambaran yang jelas tentang penyebab pengembalian berkas (unclaimed) pasien BPJS pada rawat jalan.

\section{HASIL DAN PEMBAHASAN}

\subsection{Hasil}

\section{A. Penyebab Unclaimed Berdasarkan Input}

\section{Sumber Daya Manusia (SDM)}

Berdasarkan hasil wawancara yang dilakukan kepada 6 orang petugas tentang Sumber Daya Manusia (SDM) dalam mengerjakan berkas klaim BPJS pada rawat jalan diperoleh sebagai berikut:

"Kalau untuk jumlah petugasnya sudah mencukupi dan untuk kualitasnya juga sudah baik". (Informan 1 dan 6).

Berbeda dengan hasil wawancara yang dilakukan kepada informan 2,3,4 dan 5 yang mengatakan bahwa:

"Untuk petugasnya masih belum mencukupi karena petugas hanya ada 2 orang, kurang sebanding dengan jumlah SDM nya dengan beban kerjanya.Petugas yang menangani berkas klaim BPJS Pada rawat jalan mengerjakan berkas mulai dari verifikasi, koding, mengkalim berkas.Sedangkan untuk kualitas petugas kodenya masih kurang karena tidak ada sertifikat pelatihan bagi koder yang dilakukan".

\section{Sarana}

Berdasarkan hasil wawancara yang dilakukan kepada informan tentang sarana yang digunakan dalam mengolah berkas klaim BPJS pada rawat jalan diperoleh sebagai berikut: "Untuk sarananya sudah mencukupi dan sudah baik". (Informan 6) Berbeda dengan hasil wawancara yang dilakukan kepada informan 1,2,3,4 dan 5 yang mengatakan bahwa:

"Kalau masalah sarananya masih banyak yang kurang seperti scanner dan printernya yang masing-masing terdapat 1 Mesin scanner dan printernya ini bukan hanya petugas pengelola klaim BPJS pada rawat jalan yang memakasinya tapi petugas yang menangani klaim BPJS rawat inap juga memakainya. Jadi kadang kalau rusak harus menunggu buat diperbaiki dulu mesinnya, jadi terkadang berkasnya menumpuk".

\section{Teknologi}


Berdasarkan hasil wawancara yang dilakukan kepada informan tentang teknologi yang digunakan dalam mengklaim BPJS pada rawat jalan diperoleh sebagai berikut:"Kalau mengoperasikan INA-CBGs tidak ada yang sulit, gampang kok.Yah kadang hanya perubahan versi aplikasinya aja.Jaringannya terkadang error".(Informan 1,2,3,4 dan 5).

"Pengoperasiannya tidak ada yang sulit, hanya saja terkadang komputernya lodingnya lama.Kalau masalah jaringannya terkadang error dan penyebabnya itu ialah dari segi faktor internal yaitu masalah jaringan LAN dan faktor eksternal yaitu adanya perbaikan dari pusat yaitu casemix atau NCC".(Informan 6).

\section{B. Penyebab Unclaimed Berdasarkan Proses}

\section{Perencanaan}

Berdasarkan hasil wawancara yang dilakukan kepada informan tentang perencanaanberupa Standart Operasional Prosedur(SOP) yang digunakan dalam mengelola berkas klaim BPJS pada rawat jalan diperoleh sebagai berikut:

"Untuk SOP klaimnya sudah ada". (Informan 1)

Berbeda dengan hasil wawancara dari informan 2,3,4,5 dan 6 yang mengatakan bahwa :

"SOP untuk berkas klaimnya tidak ada. Yang ada hanya berita acara yang dilakukan setelah berkas diklaim atau untuk berkas yang dipending".

\section{Pengorganisasian}

Berdasarkan hasil wawancara yang dilakukan kepada informan tentang pengorganisasian berupa TIM khusus dalam menangani berkas yang terpending diperoleh sebagai berikut:

"TIM khusus sudah ada, yaitu tim komite medik dan tim verifikasi internal dari rumah sakit". (Semua informan).

\section{Pelaksanaan}

Berdasarkan hasil wawancara yang dilakukan kepada informan tentang pelaksanaanberupa alur berkas klaim BPJS pada rawat jalan diperoleh sebagai berikut:

"Alur pengajuan klaim sudah ada. Dimulai dari berkas turun dari ruangan, kemudian berkas masuk diruang pengolahan berkas klaim, berkas diperiksa kelengkapnnya (analisis), berkas dientri dan dikoding, setelah itu berkas klaim di scan, kemudian berkas di kirim ke pihak BPJS dalam bentuk harddisc. (Semua informan).

\section{Evaluasi}

Berdasarkan hasil wawancara yang dilakukan kepada informan tentang evaluasitentang berkas klaim BPJS pada rawat jalan yang dipending diperoleh sebagai berikut:

"Evalusi yang dilakukan dari rumah sakit itu ada rapat, dan itu dilakukan kalau memang terdapat kendala dalam proses pengajuan klaimdan adanya sosialisasi peraturan baru BPJS". (Semua informan).

\subsection{Pembahasan}

\section{A. Penyebab Unclaimed Berdasarkan Input}

1. Sumber daya manusia (SDM)

Sumber daya manusia ialah pegawai yang siap, mampu, dan siaga dalam mencapai tujuan organisasi (Sutrisno, 2011).Kegagalan yang sering terjadi dalam implementasi suatu kebijakan salah satunya disebabkan oleh manusia yang tidak mencukupi ataupun tidak memadai sehingga menurunkan mutu dari suatu pelayanan. 
Berdasarkan dari hasil wawancara maupun observasi menyatakan jumlah SDM terkait petugas klaim pada rawat jalan masih kurang karena hanya berjumlah 2 orang.Petugas penglaiman BPJS pada rawat jalan mengerjakan berkas klaim mulai dari verifikasi data, koding, audit, hingga menginput data.Sedangkan untuk kualitas petugas dalam mengkoding masih kurang karena kurangnya pelatihan.Akan tetapi dilihat dari pendidikan petugas sudah baik yang pada umumnya ialah D3 rekam medis.

Hal ini tidak sejalan dengan penelitian Septiani (2016) di RSUD dr.Soekardjo bahwa SDM sudah mencukupi tetapi dilihat dari tingkat pengetahuan dan kedisplinan petugas klaim masih belum memenuhi hal ini dapat dilihat dari pengentrian berkas yang seharusnya tidak dientrikan.

\section{Sarana}

Sarana ialah segala sesuatu yang dapat dipakai sebagai alat dalam mencapai maksud dan tujuan.Kelengkapan dan sarana yang baik merupakan hal yang sangat penting dalam menciptakan proses dan target yang dicapai.

Berdasarkan hasil wawancara dan observasi tentang sarana dalam pengklaiman berkas BPJS pada rawat jalan masih kurang, seperti printer dan snanner yang masing-masing hanya terdapat 1.

Hal ini sejalan dengan penelitian Septiani (2016) di RSUD dr.Soekardjo dengan hasil penelitiannya menyebutkan bahwa kurangnya perlengkapan alat-alat seperti printer sehingga terjadi penumpukan berkas dimana-mana yang dapat mengindikasi terjadinya berkas tercecer.

\section{Teknologi}

Kemajuan teknologi sangat mendukung dalam proses kerja sehingga lebih praktis dan efisien. Teknologi ialah suatu yang digunakan untuk mengolah data. Pengolahan itu termasuk memproses, mendapatkan, menyusun, menyimpan, memanipulasi data dalam berbagai cara untuk menghasilkan informasi yang berkualitas (Uno, 2011).

Berdasarkan hasil wawancara terhadap petugas dalam mengoperasikan aplikasi INA-CBGs tidaklah sulit, akan tetapi dalam pengentrian berkas klaim BPJS pada rawat jalan terkadang petugas mengalami hambatan berupa jaringan yang terkadang error dan software yang terkadang loading lama.

Hal ini sejalan dengan penelitian (Septiani, 2016) di RSUD dr.Soekardjo menyebutkan bahwa untuk aplikasi program INA-CBGs dalam pengentrian berkas klaim berkas BPJS rawat inap terkadang error berkisar antara 5-10 menit sehingga menghambat dalam pengentrian berkas.

\section{B. Penyebab Unclaimed Berdasarkan Proses}

\section{Perencanaan}

Perencanaan merupakan pedoman, garis-garis besar atau petunjuk-petunjuk yang harus dituruti jika menginginkan hasil yang baik sebagaimana direncanakan. Tujuan perencanaan ialah memberikan pengarahan, pedoman, garis-garis besar atau petunjuk-petunjuk yang harus dituruti. Perencanaan pada hakikatnya menyusun konsep dan kegiatan yang akan dilaksanakan yang biasanya berupa Standar Operasional Prosedur (SOP) (Sarinah, 2017).

Berdasarkan hasil observasi yang dilakukan, peneliti tidak menemukan Standar Operasional Prosedur (SOP) dalam pengajuan pengklaiman berkas BPJS maupun berkas yang dikembalikan setelah di klaim (unclaimed). 
Hal ini berjalan dengan penelitian Septiani (2016) di RSUD dr.Soekardjo menyebutkan bahwa masih belum tersedianya SOP (Standar Operating Procedure) yang terkait klaim pending BPJS.

\section{Pengorganisasian}

Pengorganisasian ialah pengelompokan berbagai kegiatan yang diperlukan untuk melaksanakan suatu rencana sedemikian rupa sehingga tujuan yang telah ditetapkan dapat dicapai dengan memuaskan (Syafrudin, 2009). Sejalan dengan hal ini menurut Permenkes no. 27 tahun 2014 mengemukakan bahwa salah satu upaya yang dilakukan rumah sakit untuk melaksanakan program pemerintah terkait BPJS salah satunya dengan membangun tim rumah sakit.

Berdasarkan hasil penelitian Terkait pengorganisasian dalam pengklaiman berkas BPJS pada rawat jalan, sudah terdapat tim verifikasi iternal, komite medik dan tim pengelola berkas yang terpending.

Hal ini sesuai dengan penelitian Septiani (2016) di RSUD dr.Soekardjo bahwa sudah terbentuk tim khusus untuk pengelolaan klaim BPJS yaitu Tim Jaminan Kesehatan Nasional (JKN) sesuai dengan SK direktur.

\section{Pelaksanaan}

Pelaksanaan merupakan usaha untuk menciptakan kerjasama diantara pelaksana kegiatan sehingga tujuan organisasi tercapai secara efektif dan efisien (Syafrudin, 2009).Pelaksanaan suatu program sangat dipengaruhi dengan berjalannya alur sesuai dengan yang telah ditetapkan.

Pelaksanaan pengklaiman berkas BPJS pada rawat jalan sudah baik, dikarenakan memiliki alur pengajuan klaim dimulai dari pasien pulang pada rawat jalan, kemudian berkas masuk diruang pengolahan berkas klaim, berkas diperiksa kelengkapnnya (analisis), berkas dientri dan dikoding, setelah itu berkas klaim di scan, kemudian berkas di kirim ke pihak BPJS dalam bentuk hard disk.

Hal ini sesuai dengan penelitian Septiani (2016) di RSUD dr.Soekardjo yaitu pengajuan klaim sudah berjalan sesuai dengan juknis verifikasi yang dibuat oleh BPJS dan sesuai dengan alur yang telah ditetapkan oleh rumah sakit.

\section{Evaluasi}

Evaluasi ialah kegiatan untuk membandingkan antara hasil yang telah dicapai dengan rencana yang telah dibuat atau ditentukan. Hasil guna dari perencanaan dan pelaksanaan program, serta memberikan petunjuk dalam pengelolaan manajemen rumah sakit(Rustiyanto, 2010).

Berdasarkan hasil wawancara dengan petugas, evaluasi dilakukan apabila terdapat kendala dalam proses pengajuan klaim dan adanya sosialisasi peraturan baru terkait klaim BPJS pada rawat jalan.

Hal ini sesuai dengan penelitian (Septi, 2016) di RSUD dr.Soekardjo yaitu evaluasi dilaksanakan apabila terdapat masalah atau kendala dalam proses pengajuan klaim.

\section{KESIMPULAN}

Penyebab pengembalian berkas (unclaimed) pasien BPJS pada rawat jalan di rumah sakit umum Imelda pekerja Indonesia ialah sebagai berikut :

1. Penyebab unclaimed berdasarkan input ialah kurangnya jumlah SDM, sarana yang kurang memadai, dan teknologi sepeti jaringan dan software yang terkadang error.

2. Penyebab unclaimed berdasarkan proses ialah perencanaan yang masih belum terdapat SOP pengajuan klaim.

\section{REFERENCES}


Arikunto, Suharsini. 2010. Prosedur Penelitian suatu pendekatan praktik. Jakarta: Rineka Cipta

Departemen Kesehatan RI.2008. Permenkes No.269 /MENKES/PER/III. 2008. TentangRekam Medis. Jakarta: Departemen Kesehatan RI.

Departemen Kesehatan RI. 2009. Undang-undang Republik Indonesia Nomor 44 Tahun 2009. Rumah Sakit. Jakarta: Departemen Kesehatan RI.

Departemen Kesehatan RI. 2009. Undang-undang Republik Indonesia Nomor 36. 2009. Kesehatan.Jakarta: Departemen Kesehatan RI.

Departemen Kesehatan RI . 2011. Undang-undang No.24 2011. Badan Penyelenggara Jaminan Sosial. Jakarta: Departemen Kesehatan RI.

Indrayadi, Rano. 2017.Rekam Medis. Jakarta : Universitas Terbuka.

Isgiyanto, Awal. 2009. Teknik Pengambilan Sampel. Yogyakarta : Mitra Cendikia

Notoatmodjo, Soekidjo. 2012. Pengembangan Sumber Daya Manusia. Jakarta: Rineka Cipta

Panggabean, T. N., \& Sianipar, E. (2018). Analisis Sistem Pelepasan Informasi Rekam Medis Dalam Menjamin Aspek Hukum Kerahasiaan Rekam Medis Di Rumah Sakit Imelda Pekerja Indonesia Medan Tahun 2018. Jurnal Ilmiah Perekam Dan Informasi Kesehatan Imelda, 3(1).

Rustiyanto, Ery. 2010. Statistik Rumah Sakit Untuk Pengambilan Keputusan. Yogyakarta : Graha Ilmu.

Sarinah. 2017. Pengantar manajemen. Yogyakarta : Depublish.

Saryono dan Mekar S.A. 2013.Metodologi Penelitian Kualitatif dan Kuntitatif Dalam Bidang Kesehatan. Yogyakarta: Nuha Medika.

Sutrisno, Edy. 2011. Manajemen Sumber Daya Manusia. Jakarta: Kencana.

Syafrudin SKM, M.Kes. 2009. Organisasi Dan Manajemen Pelayanan Kesehatan. JakartaTimur: Trans Info Media.

Uno \& Nina. 2011. Teknologi komunikasi dan Informasi Pembelajaran. Jakarta : Bumi Aksara.

Valentina., \& Halawa, M. N. S. (2018). Analisis Penyebab Unclaimed Berkas BPJS Pasien Rawat Inap Di Rumah Sakit Umum Imelda Pekerja Indonesia (RSU IPI) Medan. Jurnal Ilmiah Perekam Dan Informasi Kesehatan Imelda, 3(2), 480-485. 


\section{BIOGRAPHIES OF AUTHORS}

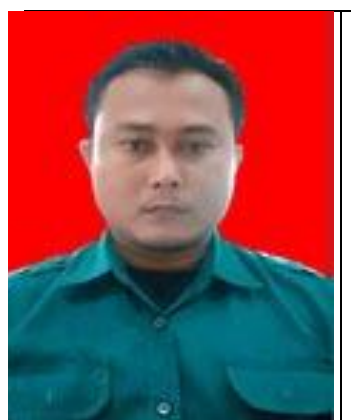

Ary Syahputra Wiguna, Gelar Sarjana diperoleh dari STMIK LOGIKA MEDAN, Jurusan SISTEM INFORMASI pada Tahun 2012. Magister Ilmu Komputer diperoleh dari Universitas Putra Indonesia YPTK Padang pada Tahun 2014. Saat ini aktif sebagai pengajar di Program Studi D-III Perekam Medis dan Informasi Kesehatan Universitas Imelda Medan. 